\title{
PEMODELAN DAN ANALISA STRUKTUR MEKANIKA PADA KONTROL SISTEM ADAPTIF END EFFECTOR DENGAN DYNAMIXEL AX-18A MOTOR SERVO
}

\author{
Lydia Anggraini ${ }^{1, a}$, Ardhi Bebi Laksono² \\ ${ }^{1}$ Program Studi Teknik Mesin, President University, Jawa Barat, Indonesia \\ ${ }^{2}$ Program Sarjana Teknik Mesin, President University, Jawa Barat, Indonesia \\ alydia.anggra@president.ac.id
}

\begin{abstract}
Abstrak. Tujuan utama dari proyek ini adalah untuk memberikan kontribusi secara deskriptif terhadap pemahaman perancangan adaptif end-effector yang dikombinasikan dengan motor servo. Simulasi dan perancangan alat ini terletak pada ujung lengan robot, yang mana merupakan salah satu topik yang paling banyak diteliti dalam dunia robotik dan industri otomasi. End-effector merupakan sistem perancangan pada sebuah proses otomasi yang harus memperhitungkan banyak kemungkinan dari respon statika dan mekanika dalam pengembangan menghadapi persaingan yang sangat ketat di dunia industri. Untuk menentukan perangkat tambahan pada suatu robot, endeffector akan didesain dengan mempertimbangkan dari berbagai kemungkinan yang terjadi pada berbagai variasi terhadap respon benda kerja, sehingga dapat mensimulasikan berbagai tingkat gesekan dan tekanan maupun pengaruh dari kontak end-effector dengan berbagai bentuk benda. Thesis ini memperkenalkan proses desain terpadu untuk desain Gripper dua jari dengan menggunakan simulasi. Untuk memfasilitasi desain terpadu dari Gripper, penulis memakai perangkat lunak Matlab R2015a

/ Simulink (SimMechanics) dan Inventor sebagai 3D Cad Model. Motor Servo yang akan digunakan disini adalah jenis motor servo Dynamixel AX-18A yang mempunyai kecepatan 97RPM dan Torsi sebesar 1,8 N.m dengan tegangan 12Volt. Untuk menghadapi revolusi industri 4.0 maka desain dan rancangan seperti alat ini akan membantu dalam proses improvisasi seiring teknologi yang semakin berkembang pesat dengan harapan dapat meminimalisir pengeluaran biaya yang berlebihan ketika melakukan improvement. Dari thesis ini bisa dilihat respon power, torque, speed, power in, power out, effeiciency dan current. Ketika suatu kasus memerlukan spesifikasi tertentu maka dengan perhitungan ini bisa dengan mudah menyelesaikan permasalahan hanya dengan mengganti motorservo yang sesuai dengan spesifikasi yang dikehendaki.
\end{abstract}

Kata kunci. End Effector, Dynamixel, Matlab Simscape, Simechanics, Adaptif

Abstract. The main objective of this project is to make a descriptive contribution to the understanding of adaptive end-effector design combined with servo motors. The simulation and design of this tool is located at the end of the robotic arm, which is one of the most researched topics in the world of robotics and the automation industry. End-effector is a design system in an automation process that must take into account the many possibilities of statics and mechanical responses in the development of facing intense competition in the industrial world. To determine the enhancements on a robot, the end-effector will be designed taking into account the various possibilities that occur in various variations on the workpiece response, so that it can simulate various levels of friction and pressure as well as the effects of end-effector contacts with various objects. This thesis introduces an integrated design process for the design of two-finger Gripper using simulation. To facilitate the integrated design of the Gripper, the author uses Matlab R2015a software

/ Simulink (SimMechanics) and Inventor as a 3D Cad Model. The Servo motor that will be used here is a type of Dynamixel AX-18A servo motor which has a speed of 97RPM and Torque of 1.8 $N . m$ with a 12 Volt voltage. To deal with the industrial revolution 4.0, design and design such as this tool will help in the process of improvisation as technology is growing rapidly in the hope of minimizing excessive costs when making improvements. From this thesis can be seen the power 
response, torque, speed, power in, power out, efficiency and current. When a case requires certain specifications, then with this calculation it can easily solve the problem simply by replacing the motors that are in accordance with the desired specifications.

Keywords. End Effector, Dynamixel, Matlab Simscape, Simechanics, Adaptif

\section{PENDAHULUAN}

Seiring perkembangan teknologi, maka perusahaan dituntut untuk meningkatkan produktifitas, kualitas, kuantitas dan efisiensi produksi. Kondisi di area proses produksi telah mengalami banyak perubahan dan berbagai tuntutan yaitu High Mix Low Volume dimana proses manufaktur sebuah produk dengan banyak variasi namun dituntut untuk biaya yang rendah. Salah satu faktor tujuannya adalah lingkungan yang membutuhkan fleksibilitas yang lebih besar dan salah satu solusi otomasi yaitu dengan sistem robotik sebagai penghemat biaya untuk pertumbuhan yang berkelanjutan.

Mengambil dan menempatkan benda kerja dalam pekerjaan yang berulang merupakan tugas yang sangat penting dalam robotika. Robot mengambil produk dari satu lokasi ke lokasi lainnya. Sebuah sistem otomatisasi dapat mempercepat proses karena bagi manusia gerakan yang berulang membutuhkan durasi yang lama dan mengakibatkan masalah kelelahan yang mungkin akan terjadi (Iida, 2013). Selain itu, robot lebih akurat. Tugas ini telah digunakan secara ekstensif diberbagai industri. Oleh karena itu, desain Gripper yang bersifat adaptif mampu memilih dan menempatkan berbagai objek dari bentuk dan permukaan yang berbeda adalah suatu tugas dan konsep yang fungsional.

Revolusi industri merupakan proses perubahan secara besar-besaran pada aspek-aspek seperti teknologi, manufaktur, transportasi, dan mempunyai dampak yang sangat kuat terhadap kondisi sosial maupun ekonomi. Hingga saat ini, dunia sudah mengalami tiga kali revolusi industri. Pada tahun 1950-an, revolusi industri ketiga terjadi dengan adanya pengembangan pada sistem digital, teknologi informasi, sehingga memungkinkan muncul cara-cara baru untuk menghasilkan output, memproses input, dan berbagi informasi.

Perkembangan teknologi yang sangat pesat saat ini bukan lagi menjadi kelanjutan untuk revolusi industri ketiga, melainkan menjadi gerbang untuk datangnya revolusi industri keempat atau industri 4.0. (Schwab, 2016) Mengartikan industri 4.0 ini sebagai cyber-physical systems yang berarti teknologi bukan lagi menjadi 'alat' melainkan tertanam pada kehidupan masyarakat. Collaborative Robot, artificial Intelligence, nanotechnology, biotechnology, autonomus vehicles, dan 3D printing merupakan contoh semakin luasnya perkembangan teknologi saat ini.

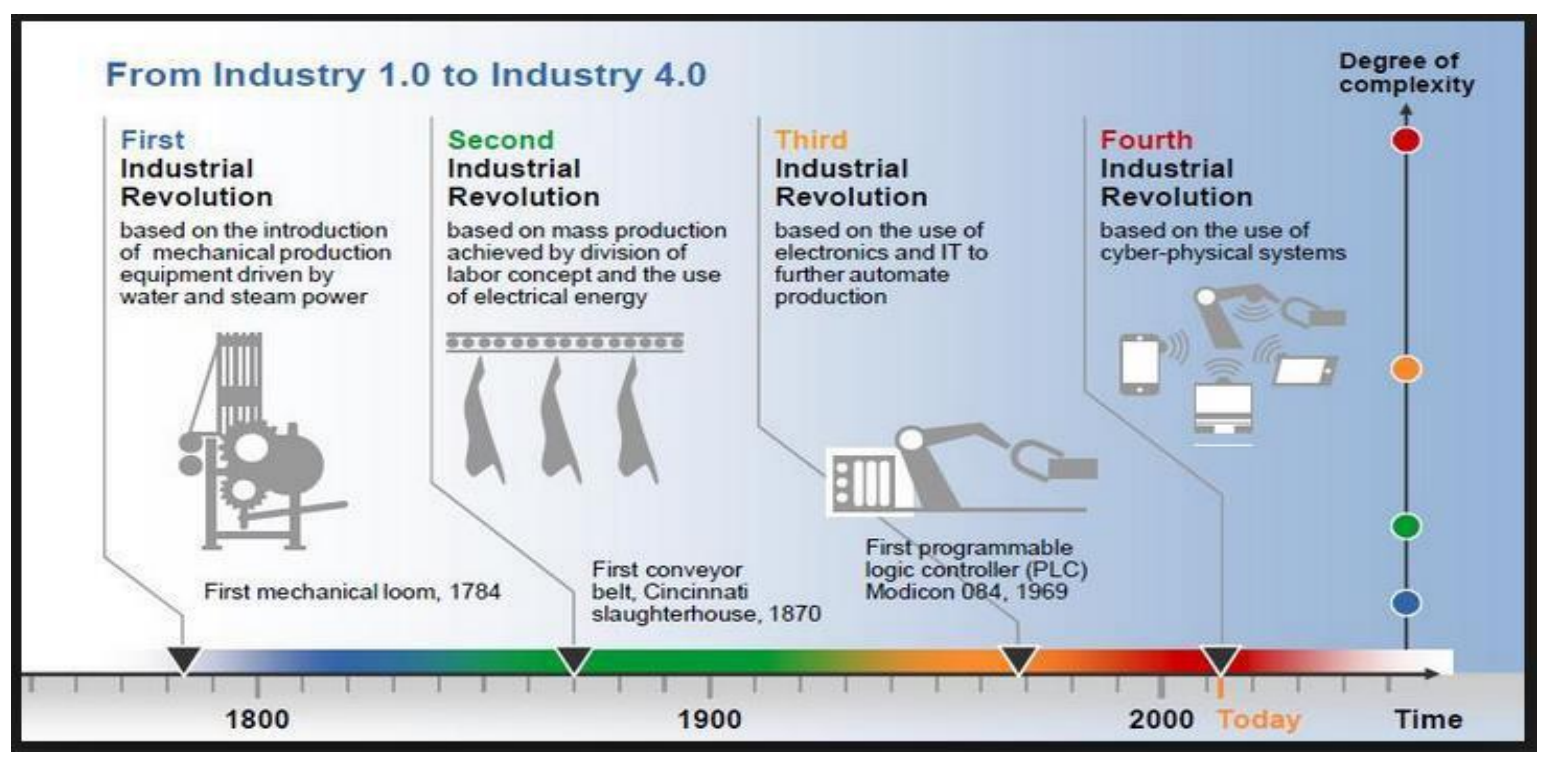

Gambar 1.1 Revolusi Industri

Manfaat dan tantangan tentunya akan muncul seiring berkembangnya revolusi industri ke empat ini. Seperti semakin luasnya perkembangan finansial teknologi, dan juga manufaktur dalam hal 
produktifitas dan efisiensi. Lalu, disparitas tenaga kerja akan muncul sebagai tantangan untuk revolusi industri ini dimana banyak perusahaan yang akan mengedepankan modal mesin (capital intensive) daripada modal tenaga kerja.

Revolusi Industri keempat merupakan tantangan terbesar yang harus dihadapi saat ini karena tidak hanya mempengaruhi pasar tenaga kerja ataupun perilaku produsen dan konsumen saja tetapi secara keseluruhan mempengaruhi kehidupan sosial dan ekonomi. (Columbus, 2016) Untuk mengatasinya seluruh masyrakat harus berkembang secara komprehensif dan melihat dari berbagai sisi bagaimana teknologi dapat mempengaruhi kehidupan baik ekonomi, sosial, budaya serta lingkungan hidup sehingga dapat membentuk tatanan hidup yang baru dan pemerintah harus berpikir secara sistematis dan strategis akan adanya transformasi teknologi (Schwab, 2016).

\section{METODOLOGI PENELITIAN}

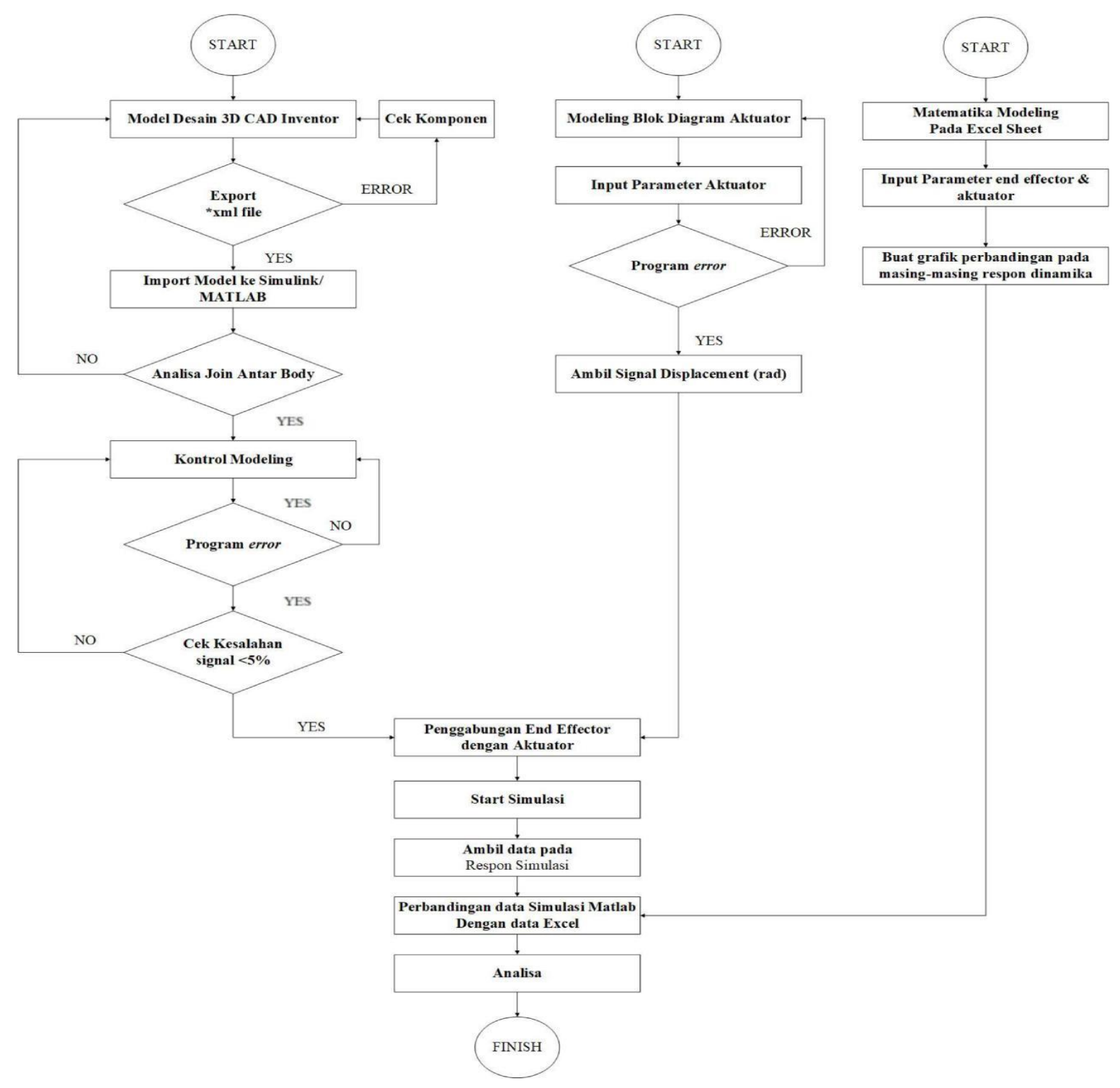

\section{Tahap 1 pemodelan end-effector}

Pada pengerjaan studi kasus ini dimulai dari pembuatan desain 3D CAD dengan software Autodesk Inventor yang kemudian di export kedalam bentuk XML file. Sebelum XML file dikonversi kedalam bentuk blok diagram maka perlu adanya pengencekan pada masing-masing komponen. Setelah dinyatakan OK maka dilakukan tahap konversi dari XML file ke dalam blok diagram dengan menggunakan perintah smimport('name_file'). Kemudian analisa join antar body dengan menggunakan update diagram. Setelah sampai tahap ini sudah dinyatakan OK maka dilakukan 
kontrol modeling, dimana pada tahap ini merupakan pembuatan modeling sebelum revoluter pada body digerakan oleh aktuator. Setelah itu, cek program error dan cek kesalahan masing-masing sambungan pada tiap body khususnya pada Link 1 .

\section{Tahap 2 pemodelan actuator}

Tahap kedua setelah membuat konfigurasi end-effector yaitu tahap pembuatan modeling sebuah aktuator. Pada tahap ini cukup simpel karena tidak menggunakan modeling pada 3D CAD, yaitu dengan tahap pembuatan konfigurasi dengan blok diagram Simulink pada Matlab. Pada tahap pembuatan konfigurasi ini harus diperhatikan dengan matematika modeling pada kondisi aktualnya. Setelah selesai maka parameter aktuator harus dimasukan kedalam blok diagram sesuai dengan parameter yang ada pada katalog robotis. Setelah itu dilakukan pengcekan program dengan start simulation, jika program error maka akan mengeluarkan warning beserta penanganannya. Kemudian setelah konfigurasi dan parameter sudah dinyatakan OK, maka ambil output signal dari displacement pada Rotational Motion Sensor (A).

\section{Tahap 3 pemodelan pada Excel Sheet}

Pada tahap ketiga ini adalah proses perhitungan pada excel sheet dengan menggunakan rumusrumus teori yang telah dipelajari dikelas. Pada pengerjaan perhitungan data pada program excel yaitu dimulai dengan memasukan rumus-rumus dinamika yang diperoleh dari sumber yang terpercaya kemudian memasukan parameter-parameter yang ada pada perhitungan excel, dan hasilnya disimpulkan dalam bentuk grafik.

\section{Tahap 4 integrasi antara end effector dengan aktuator}

Pada tahap terakhir ini yaitu tahap dimana dilakukannya penggabungan antara end effector dengan aktuator untuk hasil simulasi dan kemudian dianalisa. Pada tahap penggabungan ini

yaitu dimana revoluter pada blok diagram end effector digerakan oleh output displacement yang dihasilkan oleh blok diagram aktuator. Setelah penggabungan konfigurasi selesai maka dilakukan proses simulasi untuk melihat gerak respon dinamika. Hasil respon dinamika ini akan dibandingkan dengan hasil perhitungan melalui excel sheet yang telah dikerjakan pada tahap 3. Kemudian hasil perbandingan tersebut dianalisa, projek goal pada analisa ini adalah hasil simulasi pada matlab harus sama dengan hasil perhitungan pada excel sheet dimana menggunakan metode theoretical dan mathematical yang sudah dipelajari selama dikelas dengan menggunakan sumber-sumber yang terpercaya.

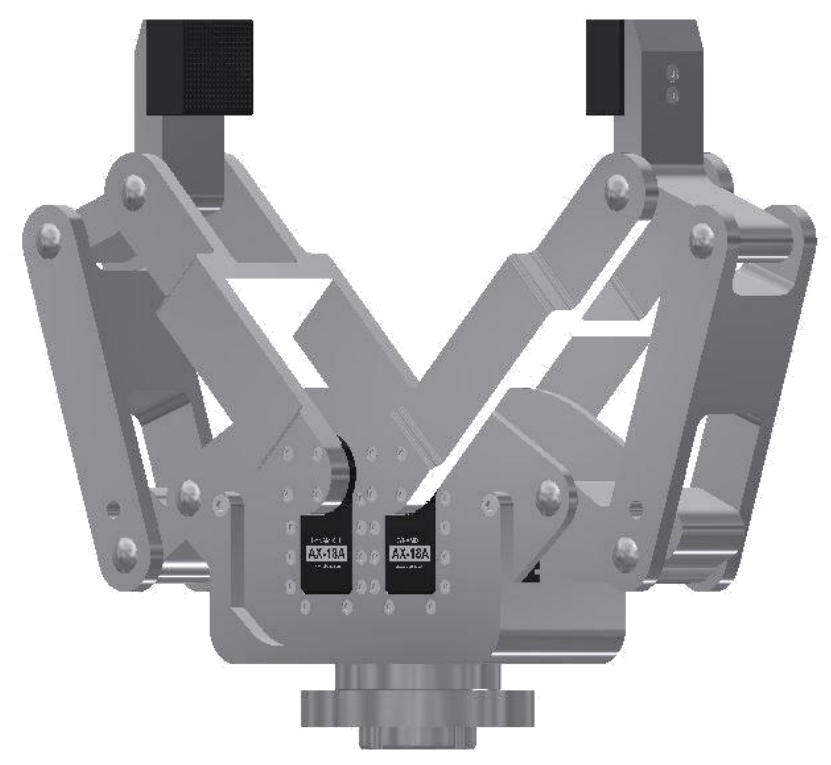

Gambar 3.11 3D End Effector 


\section{Modeling End Effector}

DC servomotor digunakan untuk menggerakkan sendi jari-jari dari pemodelan Gripper tangan dua jari yang ditunjukan pada Gambar 3.11 3D End Effector. Ada dua macam join pada jari-jari Gripper ini seperti proximal interphalangeal (PIP) dan metacarpophalangeal (MCP) dimana setiap sendi mempunyai satu sendi putar. Gripper ini memiliki 2 DC servomotor yang dipasang pada join MCP saja. Untuk menggerakkan sendi PIP akan digunakan system mekanik yang berputar.

Gripper dipilih dengan motorservo aktuator karena saya pikir itu adalah cara termurah dan itu sangat praktis dan mudah untuk dibuat. Saya harus mengambil keputusan lain sebelum menyelesaikan desain saya. Saya memutuskan untuk menggunakan hanya dua Gripper ("dua jari") bukan tiga atau lebih jari dengan tujuan menghemat bahan dan membuat Gripper robot semurah mungkin.

Sepanjang pengembangan proyek saya, saya telah mencoba dengan desain yang berbeda untuk akhirnya mendapatkan Gripper paling efektif yang saya temukan.

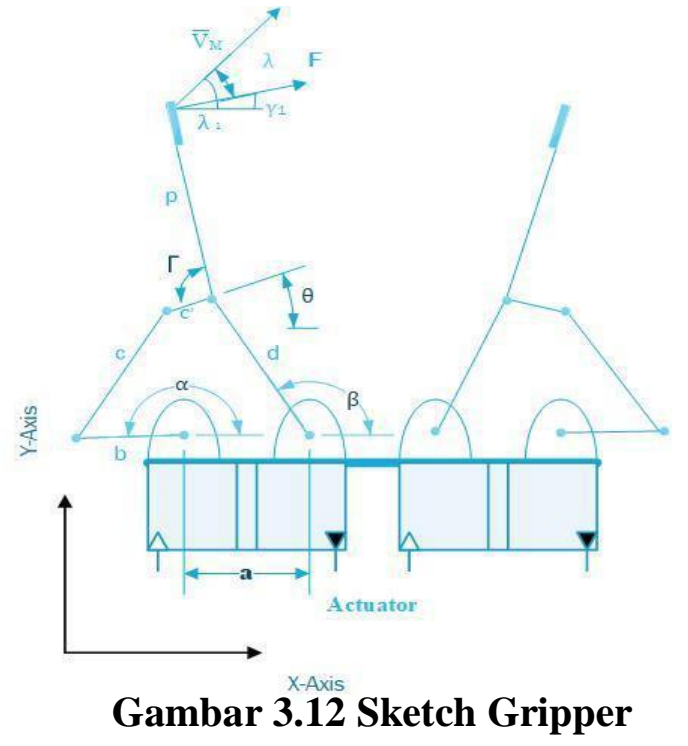

Akhirnya, saya telah menemukan Grippers dengan tujuan yang adaptif bahwa jarak minimum dan maksimunya bisa diatur sesuai kebutuhan dengan menggunakan servomotor.Gripper robot ini memiliki 2DOF dan terdiri dari beberapa bagian utama:

Pada Gambar 3.13 Assembly 3D CAD End effector tersebut sudah dijelaskan semua struktur desain beserta massa pada masing-masing part. Pemodelan kinerja mesin sangat penting untuk mengembangkan pemahaman intuitif tentang bagaimana sistem berjalan. Selain itu, kita harus terus menguji intuisi dan model ini dengan membandingkannya dengan kinerja mesin yang sebenarnya. Bab ini menjelaskan upaya untuk mengukur respons Gripper robot di laboratorium dengan tiga tujuan dalam pikiran. Pertama, kita membutuhkan pengukuran parameter yang diketahui dalam aktuator. Kedua, kita membutuhkan data nyata yang dapat digunakan untuk menilai validitas model matematika. Ketiga, saya ingin mengamati perilaku sistem yang sebenarnya terhadap respon pada simulasi sehingga jika model ini bisa mendekati hasil yang maksimal, maka saya membuat model baru dengan menyertakan efek respon Dinamika. (Bahkan, banyak data laboratorium yang kualitatif telah digunakan dalam pembuatan model, tetapi di sini saya bermaksud untuk mengumpulkan data secara kuantitatif.) 


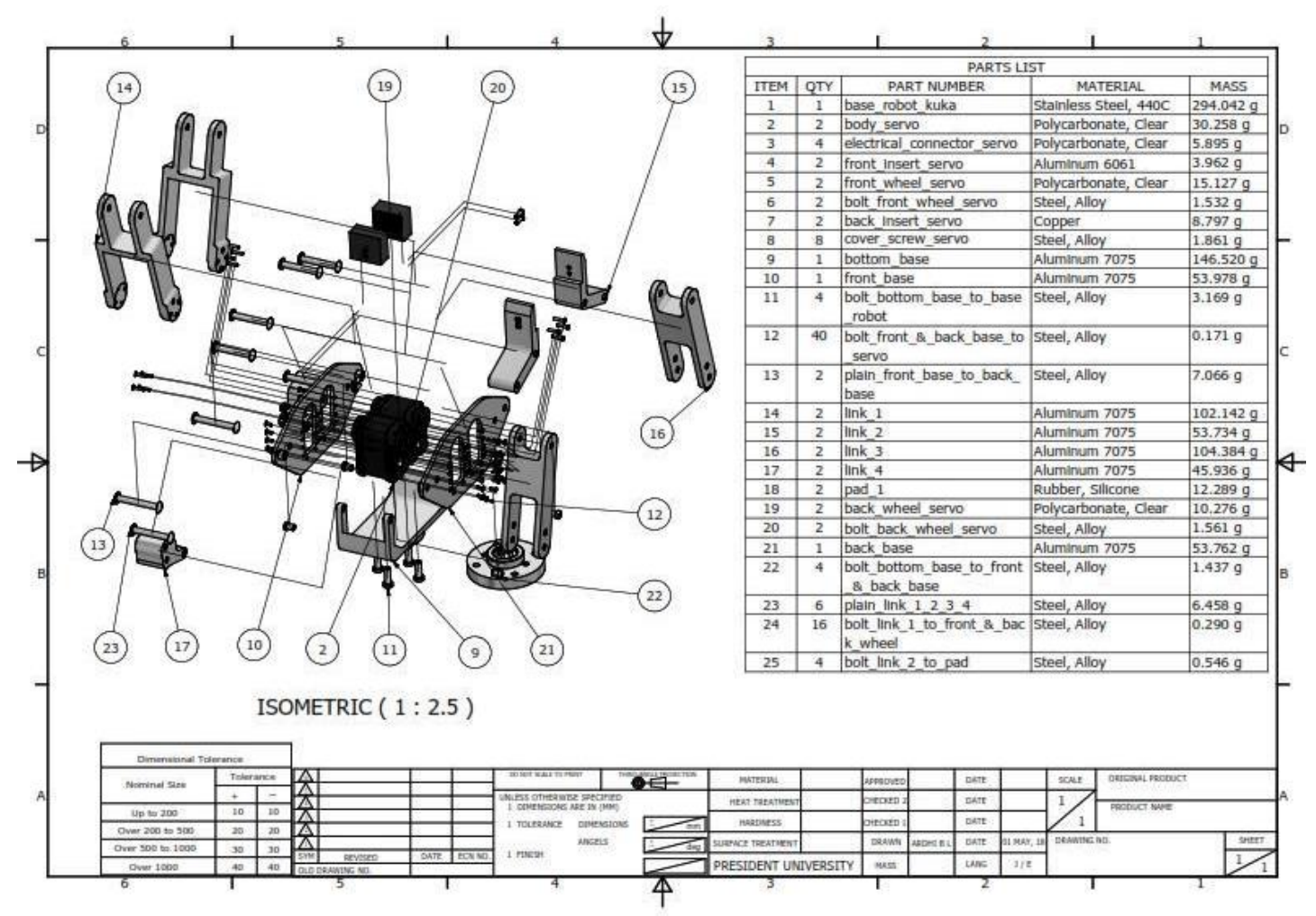

Gambar 3.13 Assembly 3D CAD End effector

\section{Blok Diagram 3D End Effector Simmechanics}

SimMechanics TM menyediakan lingkup simulasi multibodi untuk sistem mekanik 3D, seperti robot, suspensi kendaraan, peralatan konstruksi, dan landing gear pesawat. Kita dapat memodelkan sistem multibodi menggunakan blok yang teridiri dari sambungan, sendi, solid body, dan elemen gaya, dan kemudian SimMechanics merumuskan dan memecahkan persamaan gerak ke sistem mekanik yang lengkap. Model dari sistem CAD, termasuk mass, inersia, joint, constraint, dan 3D geometry, dapat diimpor ke SimMechanics. Animasi 3D yang dihasilkan secara otomatis memungkinkan kita untuk memvisualisasikan dinamika system.

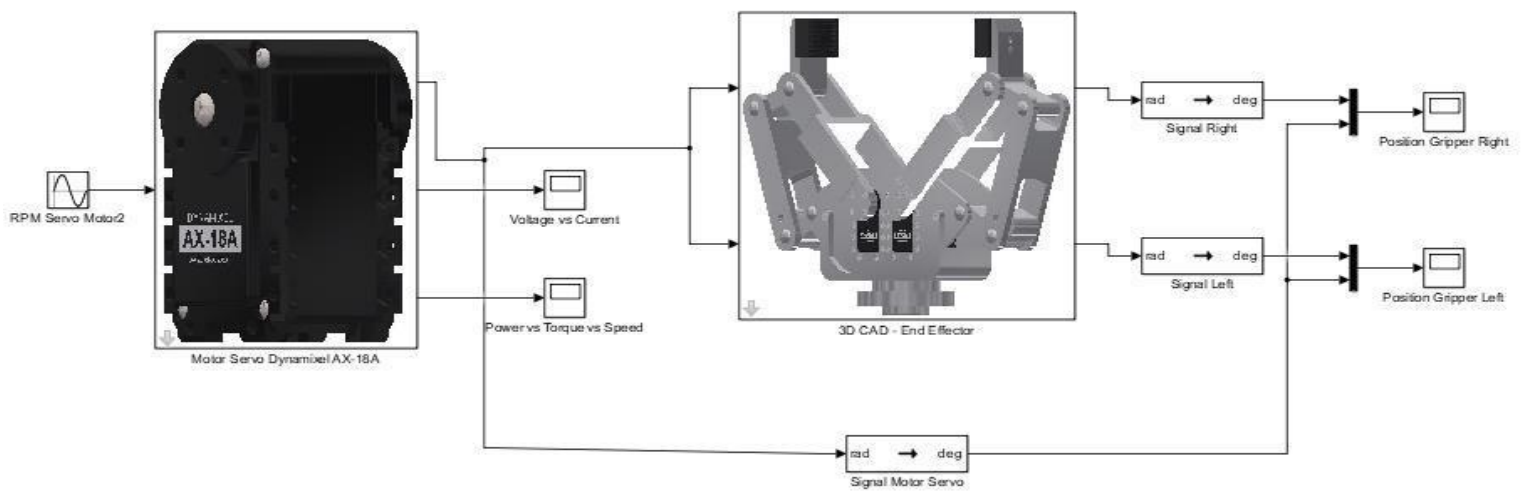

\section{Gambar 3.14 Model blok diagram dengan aktuator}

SimMechanics menyediakan teknologi solver khusus untuk mensimulasikan sistem mekanik multibodi. Kita dapat melakukan berbagai jenis analisis, termasuk dinamika kedepan, dinamika terbalik, dan kinematika. Disini juga dapat menerapkan kekuatan dan torsi ke mesin kemudian melihat gerakan yang dihasilkan, atau menentukan gerakan dan menghitung kekuatan dan torsi yang diperlukan untuk menghasilkan gerakan itu sendiri. Dengan kemampuan ini, kita dapat 
menghasilkan dan menguji persyaratan untuk sistem aktuasi, atau melihat bagaimana struktur masing-masing bagian prostetik akan bergerak.

\section{HASIL, PEMBAHASAN DAN ANALISA}

\section{Forces End-Effector Analysis}

Kekuatan torsi pada dynamixel ax-18a adalah 1.8 N.m sama dengan 1800 N.mm. Jarak radius penggerak 108mm. Perhitungan gaya yang dihasilkan oleh motor servo adalah

$$
\mathrm{F}=\frac{1800 \mathrm{~N} \cdot \mathrm{mm}}{108 \mathrm{~mm}}=16.66 \mathrm{~N}
$$
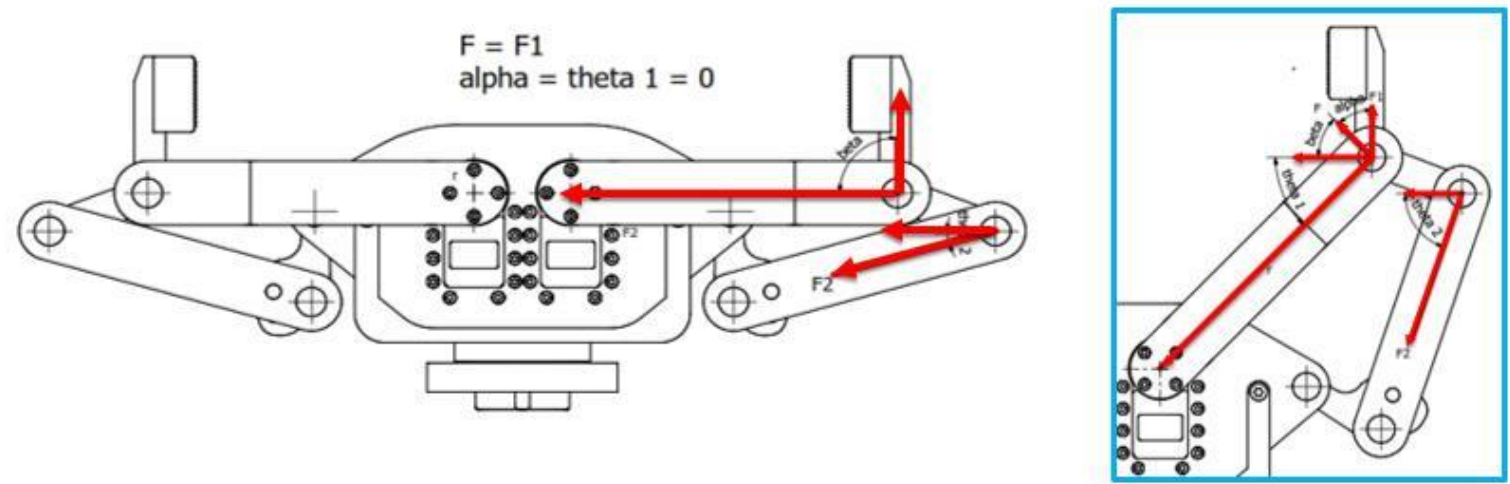

\section{Gambar 4.1 Free Body Diagram}

Nilai F menjadi sama dengan F1 dan kita memiliki kasus tertentu di sini karena gaya $\mathrm{F}$ berada di arah Gripper sehingga sudut $\alpha$ sekarang berbeda. Kita tidak perlu menghitung masing-masing komponen dalam kasus ini dan kita bisa mulai dengan resolusi dari persamaan:

$$
\begin{aligned}
& \mathrm{F}_{1}=F \cdot \cos (\alpha) \\
& \mathrm{F}_{1}=15.3^{*} \cos \left(0^{\circ}\right)=16.66 N
\end{aligned}
$$

Persamaan pertama adalah sebagai berikut:

$$
\begin{aligned}
& \Sigma F x=0 \rightarrow-F_{1} \cdot \cos (\alpha+\beta)-F_{2} \cdot \cos \left(\theta_{2}\right)+F_{\text {gripper }}=0 \\
& F_{\text {gripper }}=16 \cdot 66 \cos \left(90^{\circ}\right)+F_{2} \cdot \cos \left(15.38^{\circ}\right)
\end{aligned}
$$

$$
\text { Persamaan Kedua: } \quad F_{2}=\frac{F_{1} \cdot \sin (\alpha+\beta)}{\sin \left(\theta_{2}\right)}=\frac{16.66 \sin \left(90^{\circ}\right)}{\sin \left(15.38^{\circ}\right)}=62.81 \mathrm{~N}
$$

Dari persamaan Persamaan maka diperoleh:

$F_{\text {gripper }}=16.66 \cos (90)+62.81 \cos (15.38)=60.56 \mathrm{~N}$ 


\section{Analisa Kapabilitas Mengangkat Beban 10kg}

Untuk mengangkat benda seperti ilustrasi dibawah ini:

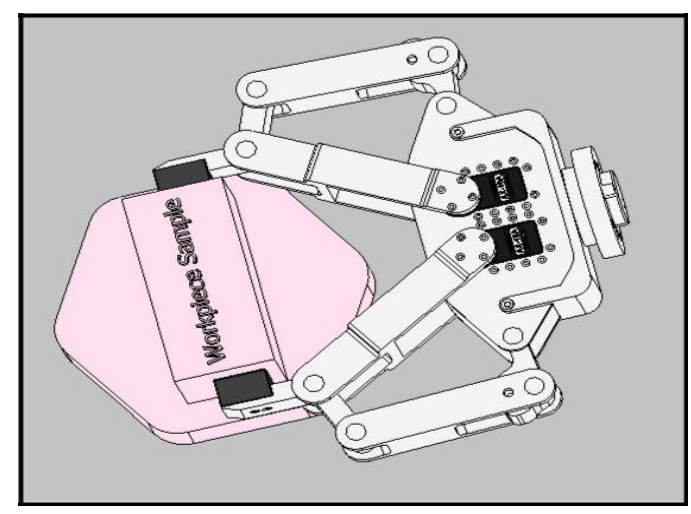

\section{Gambar 4.2 Ilustrasi End Effector memegang benda kerja}

Data pada Gambar 4.2 adalah gaya normal yang dilakukan oleh gripper saat memegang benda kerja. Dalam kasus ini kekuatan gripper tidak lebih dari 10kg.

Tabel 4-1 Koefisien Gesek Material

\begin{tabular}{|l|c|c|}
\hline \multirow{2}{*}{ Materials } & Coefficients of Static & Coefficients of Kinetic \\
\cline { 2 - 3 } & Friction $(s)$ & Friction $(k)$ \\
\hline Steel on Steel & 0.74 & 0.57 \\
\hline Aluminum on Steel & 0.61 & 0.47 \\
\hline Copper on Steel & 0.53 & 0.36 \\
\hline Rubber on Concrete & 1.0 & 0.8 \\
\hline Wood on Wood & $0.25-0.5$ & 0.2 \\
\hline Glass on Glass & 0.94 & 0.4 \\
\hline Waxed wood on Wet snow & 0.14 & 0.1 \\
\hline Waxed wood on Dry snow & - & 0.04 \\
\hline Metal on Metal (lubricated) & 0.15 & 0.06 \\
\hline Ice on Ice & 0.1 & 0.03 \\
\hline Teflon on Teflon & 0.04 & 0.04 \\
\hline Synovial joints in humans & 0.01 & 0.003 \\
\hline
\end{tabular}

Sumber: (Eng, 2001)

Gaya gesek disini adalah gaya gesek maksimum yang diijinkan.

Parameter:

$\begin{array}{ll}\text { Masa Benda } & : 10 \mathrm{~kg} \\ \text { Masa Arm Gripper } & : 0.636 \mathrm{~kg} \\ \text { Koefisien Gesek Statis } & : 1.0 \\ \text { Gaya Pada Gripper } & : 60.56 \mathrm{~N} \\ \text { Gaya gravitasi } & : 10 \frac{\mathrm{m}}{\mathrm{s}^{2}}\end{array}$


Journal of Mechanical Engineering and Mechatronics

ISSN: 2527-6212, Vol. 3 No. 1

(C) 2018 Pres Univ Press Publication, Indonesia

Ilustrasi diagram:

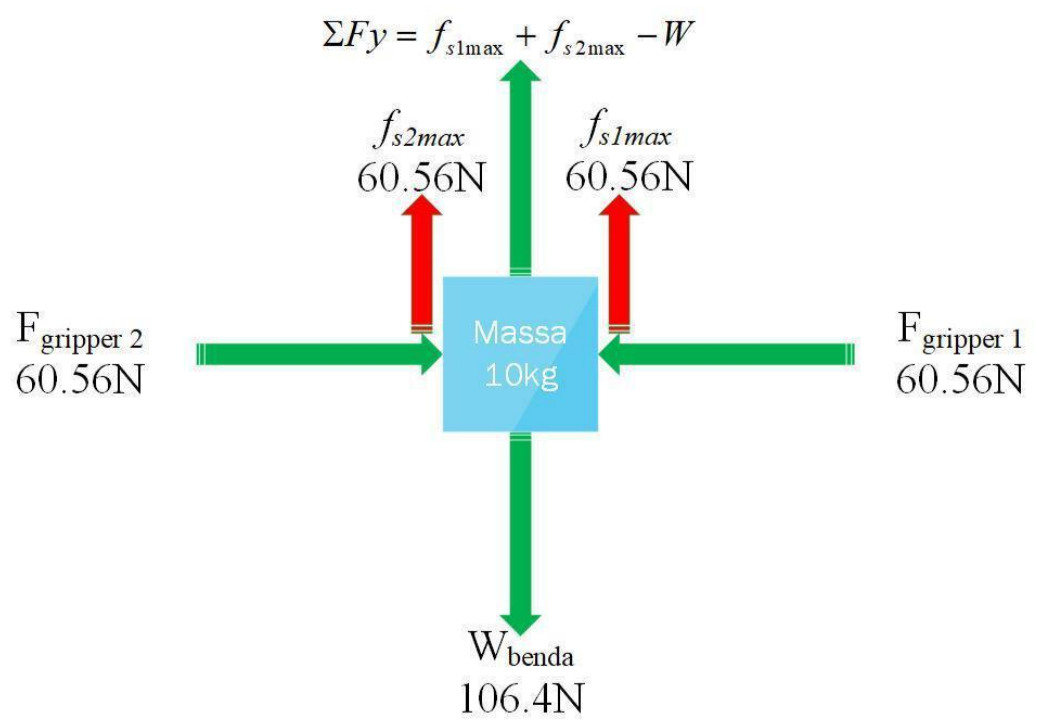

\section{Gambar 4.3 Pemodelan Analisa Resultan Gaya}

Maka persamaan menjadi

$$
\begin{aligned}
& \Sigma F x=0 \\
& F_{1}-F_{2}=0 \\
& 60.56 \mathrm{~N}-60.56 \mathrm{~N}=0 \mathrm{~N} \\
& f_{s 1,2 \max }=\mu_{s \max } \cdot N \\
& f_{s 1,2 \max }=(1) \cdot(60.56)=60.56 \mathrm{Newton} \\
& W=\mathrm{m} \cdot \mathrm{g} \\
& W=10 \mathrm{~kg}+0.64 \mathrm{~kg} \cdot 10 \frac{\mathrm{m}}{s^{2}} \\
& W=76.4 \mathrm{Newton} \\
& \Sigma F y=f_{s 1 \max }+f_{s 2 \max }-W \\
& \Sigma F y=60.56 \mathrm{~N}+60.56 \mathrm{~N}-106.4 \mathrm{~N} \\
& \Sigma F y=14.72 \mathrm{~N} \\
& R=\sqrt{\Sigma F x^{2}+\Sigma F y^{2}} \\
& R=\sqrt{0^{2}+14.72^{2}} \\
& R=14.72 \mathrm{Newton}
\end{aligned}
$$

Sudut resultan gaya yang diperoleh adalah:

$$
\begin{aligned}
& \tan \theta=\frac{\Sigma F y}{\Sigma F x} \\
& \tan \theta=\frac{6.3}{0}=(\sim) \\
& \theta=\operatorname{arc.tan}(\sim)^{\circ}=90^{\circ} \text { terhadap sumbu } x
\end{aligned}
$$


Jadi bisa ditarik kesimpulan bahwa design end-effector dengan motor servo dynamixel AX-18A mampu mengangkat beban sebesar 10kg dan masih mempunya resultan gaya ke atas $90^{\circ}$ terhadap sumbu x sebesar 14.72 Newton

\section{Angular Deflection}

\section{Perhitungan Polar Moment Inertia:}

Polar of Moment Inertia (J)

$$
\begin{array}{rrrr}
= & 0.098 \times \mathrm{D}^{4} \\
= & 0.098 \times \mathrm{N}^{4} & 22^{4} \\
= & \mathbf{2 2 9 5 7 . 0 9} \mathrm{mm}^{4}
\end{array}
$$

Perhitungan Angular Deflection:

Torque $(\tau)$

Length of Shaft (L)

Modulus of Rigidity (G)

Polar of Moment Inertia (J)

Angular Deflection $(\Theta)$

$$
\begin{aligned}
& =1800 \mathrm{~N} . \mathrm{mm} \\
& =4 \mathrm{~mm} \\
& =2208 \mathrm{MPa} \\
& =22957.09 \mathrm{~mm}^{4} \\
& =\frac{\mathrm{LxT}}{G x \mathrm{~J}}
\end{aligned}
$$

$$
\begin{aligned}
& \frac{4 \times 1800}{2208 \times 22957} \\
= & 0.000142 \mathrm{rad}
\end{aligned}
$$

Jadi Angular Deflection pada Motorservo adalah 0.000142 rad Pada material ini defleksi yang diijinkan 0.01 radian (Portnoy, 1998)

\section{Torsion Spring Constant (k)}

Perhitungan Spring Coefficient:

Force (F)

Moment Arm (M)

Deflection $(\Theta)$

$\mathrm{k}$

\section{Rotational Damper (D)}

Perhitungan Damper Coefficient:

Weight

Pulley radius

Speed required $(\mathrm{V})$

Force $(\mathrm{F})$

Force $\mathrm{x}$ Pulley radius

Speed of rotation (w)

Speed required / Pulley radius

$$
\begin{aligned}
& =163.63 \mathrm{~N} \\
& =0.011 \mathrm{~m} \\
& =0.00014 \mathrm{rad} \\
& =\quad \frac{\text { Force }(\mathrm{F}) \mathrm{x} \text { Moment } \operatorname{Arm}(\mathrm{M})}{\text { Deflection }(\theta)} \\
& =\frac{163.63 \times 0.011}{0.000142042} \\
& =12671.8 \mathrm{~N} \cdot \mathrm{m} / \mathrm{rad}
\end{aligned}
$$




\section{Use Formula 2}

Rate

Torque / Speed of rotation

$$
\begin{aligned}
& =1.79993 / 10.15784 \\
& =\mathbf{0 . 1 7 7 2} \text { N.m }(\mathbf{r a d} / \mathbf{s e c})
\end{aligned}
$$

Jadi Coefficient Damper adalah $\mathbf{0 . 1 7 7 2}$ N.m

\section{Mass Moment of Inertia (I)}

\section{Perhitungan Moment of Inertia :}

$\begin{array}{ll}\text { Massa }(\mathrm{m}) & =0.336 \mathrm{~kg} \\ \text { Jarak sumbu ( } \mathrm{r}) & 0.011 \mathrm{~m} \\ \mathrm{I} & \operatorname{Massa}(\mathrm{m}) \times \text { Jarak sumbu }(\mathrm{r}) \\ & 0.336 \times 0.000121 \\ = & \mathbf{0 . 0 0 0 0 4 0 6 5 6} \mathbf{k g . m ^ { 2 }}\end{array}$

Jadi moment inersia yang terjadi pada motor servo dynamixel AX-18A adalah 4e-5 kg.m²

\section{KESIMPULAN}

Desain end effector ini termasuk salah satu alat pendukung dalam dunia otomasi yang cukup kuat untuk mengangkat beban sampai dengan $10 \mathrm{~kg}$, kekuatan daya angkat yang dimiliki oleh end effector ini bisa dinaikan dengan hanya mengganti aktuatornya dalam catatan masih termasuk dynamixel family. Fleksibel adalah kata kunci dari desain ini, yang mana artinya bisa customize sesuai dengan kebutuhan. Jika ingin menggunakan pada robot maka cukup mengganti pada bagian base plate. Kekuatan ini tergantung pada parameter torsi yang ada pada aktuator. Semakin besar torsi maka semakin besar pula kekuatan yang dimiliki oleh end effector ini. Dalam hasil Analisa BAB IV ditunjukan bahwa power yang paling besar dicapai ketika berada di middle speed. Hasil juga menunjukan bahwa antara kecepatan dan torsi berbanding terbalik. Ketika kecepatan maksimum, maka menunjukan torsi sama dengan nol. Keseluruhan desain dan biaya manufaktur telah menghemat $71 \%$ persen dibanding dengan membeli end effector diluar yang harganya mencapai 40jt, yaitu harga pada On Robot Gripper.

\section{DAFTAR PUSTAKA}

Álvaro Meneses Martínez. (2015, June). Mechanical design of a robot's gripper. Retrieved from https://repositorio.unican.es/xmlui/bitstream/handle/10902/6523/376005.pdf?sequence=1

Chiu, S. L. (1987). "Control of redundant manipulators for task compatibility. California: Proc. IEEE International Conference on Robotics and Automation.

Cmedia. (2015). Fresh Update Mega Bank Soal Ilmu Pengetahuan Alam (IPA) SMP kelas 1, 2, \& 3. In T. G. Eduka.

https://books.google.co.id/books?id=zT_rCQAAQBAJ\&pg=PA53\&lpg=PA53\&dq=gaya+jik a+searah+ditambahkan+jika+berlawanan+dikurangkan+jika\&source=bl\&ots=RQlz_sSax9\&s ig=rkIfpwU3pS2eE7O7avTm7Q3MYjk\&hl=en\&sa=X\&ved=2ahUKEwi3h97prLraAhWFtI8 KHbJJB6gQ6AEwAHoECAAQLA\#v=on.

Columbus, L. (2016). Industry 4.0 Is Enabling a New Era of Manufacturing Intelligence and Analytics. Forbes. Swedia.

Craig, J. K. (1982). Force control and kinematic issues. International Root Res., vol. 1. 
Design, A. (2018). (Copyright (C) 2018 Garda Pengetahuan |Cara|Garda ID|TechSeo| TheBestGuide|ConseilSante|Gesundheitstipps) Retrieved 3 20, 2018, from http://www.gardapengetahuan.xyz/2012/11/pengertian-resultan-gaya.html

Eng, M. (2001). Retrieved from http://engineering.nyu.edu/gk12/Information/Vault_of_Labs /Physics_Labs/static\%20and\%20kinetic\%20friction.doc

Engineer Edge. (2000-2018). Torsion Spring Constant Formula. Retrieved from https://www.engineersedge.com/spring_torsion_calc.htm

Engineering ToolBox. (2005). Mass Moment of Inertia. Retrieved from https://www.engineeringtoolbox.com/moment-inertia-torque-d_913.html

Engineers Edge. (2000-2018). Shear modulus of Rigidity. Retrieved from https://www.engineersedge.com/materials/shear_modulus_of_rigidity_13122.htm

Engineers Edge. (2000-2018). Torsional Deflection of Solid Cilynder. Retrieved from https://www.engineersedge.com/mechanics_machines/torsional_deflection_of_shaf t_13120.htm

Gurumuda. (n.d.). Gurumuda.Net. Retrieved from https://gurumuda.net/gaya-berat-dan-gayanormal.htm

Iida, F. (2013). 2D Modeling of a Passive Compliant Gripper. Spring Term, 1.

J. Butterfass, M. F. (2004). Design and experiences with dlr hand ii. Automation Congress, Proceedings, World, vol. 15.

Jerome, L. (2013, January 09). Robot interaction finally reaches the work floor. Retrieved from generationrobot: https://www.generationrobots.com/blog/wpcontent/uploads/2014/01/Lightweight-robots-and-Collaborative-Robotics.pdf

K. B. Biggers, S. C. ( 1986). Low level control of the utah/M.I.T. dexterous hand. San Francisco: Proc. IEEE. Int Conf. Robotics and Automation.

Kinetrol, LTD. (2015). Precision Rotary Dampers for Smooth Motion Control. Retrieved from http://www.kinetrol.com/pdf/cat/Rotary_Damper_2013_LR.pdf

Kobayashi. ( 1985). "Control and geometrical considerations for an articulated robot hand. Int. Journal of Robotics Research.

Littlefield, D. H. (n.d.). MATLAB Bahasa Komputasi Teknis. Retrieved from https://amigailr.wordpress.com/2011/07/18/metoda-numerik-untuk-solusi-rangkaian-listrikmenggunakan-matlab-7/

London Metal Exchange (LME). (2018). London Metal Exchange.

Nagai, T. Y. (1998-2004). Manipulating and grasping forces in manipulation by multi-fingered hands. Proc. IEEE International Conference on Robotics and Automation.

Okada, T. (1982). "Computer control of multi-jointed finger system for precise object handling. IEEE Trans. Syst., Man, Cybern. 